\title{
An Empirical Study of Customers' Perceptions of Service Quality and Loyalty with Using Structural Equation Modeling
}

\author{
Sayyede Nasim Amirosadat \\ Master of Business Administration, Department of Management, University of Isfahan, \\ Isfahan, Iran \\ Mohammad Totian Esfahani \\ Master student of Business Administration, Department of Management, University of Isfahan, \\ Isfahan, Iran

\section{Alireza Moshkforosh} \\ Master student of Business Administration, Department of Management, University of Isfahan, \\ Isfahan, Iran \\ Email: Nasim_amt@yahoo.com
}

DOI: 10.6007/IJAREMS/v2-i4/49

URL: http://dx.doi.org/10.6007/IJAREMS/v2-i4/49

\begin{abstract}
This paper investigated the relationship between service quality and loyalty between online buyers . electronic service quality is found to be a prime determinant of consumer loyalty which is very important for the growth of any retailer industry. On this study, we have selected four most important dimensions of e-service quality which are: Reliability, Responsiveness, Ease of use, and Security.

We adopted a quantitative approach for this study and our survey took place in Isfahan city. After collecting the data we analyzed it with structural equation modeling. We found that all the four dimensions of e-service quality have strong relationship with consumer loyalty which means that they have considerable impact on building and maintaining the loyalty of online banking users. We found out that the users give the highest priority to the organization of website contents and security of transaction.
\end{abstract}

\section{Introduction}

Internet is one of the modern innovations that literally transformed the world and has become a part and parcel of our everyday life. Currently, Internet is acting as a revolutionary agent that is changing the business world in a dynamic way. With the blessings of Internet and information technology, now communication and relationship development between people from any corner of the world have become incredibly easy (Singh, Gordon \& Purchase, 2007). It is widely documented, that the Internet has opened up new ways for companies to conduct their business and interaction with customers (Lexhagen, 2009). E-commerce provides products and services through internet technologies. E-retailers- web-based retailing stores are a major 
provider of e-commerce services. Amazon is the biggest e-retailer whereas there is countless number of such stores operating locally and globally.

Consumer electronic industry has also channeled a significant portion of transactions through e-retailing outlets as well. Nowadays, almost every consumer electronic company has own websites in order to promote and sell the products and services and they use e-retail marketing to attract customers and use a variety of techniques and strategies to create consumer loyalty (Lexhagen, 2009).

Over the last two decades, the business-to-customer online retail marketing has grown rapidly. E-retailing through electronic store is growing tremendously and making a distinct place in the market compared to traditional retailing (Chang, Wang \& Yang, 2009b). Electronic commerce has emerged as an increasingly significant business phenomenon in recent years (Wu, 2011). With the growth of e-commerce, the competition is getting more intense every day. Similar to offline trading, consumer loyalty is highly important for online business. Whereas the term loyalty signifies the same notion for online and offline trading, the factors affecting loyalty is not the same for e-commerce and traditional commerce. However, the point is that loyal customers are a great asset for any company regardless of the platform the company is in. Loyal customers have a higher lifetime value as they repurchase the products. But, as the competition is quite fierce and competitors are always trying to get their pie in the market, consumer loyalty is quite a hard thing to do (Ponirin, Scott \& von der Heidt, 2010). To develop the e-service quality, e-retail stores need to ensure the high quality of e-service standard that will be able to create value in the business-to-consumer (B2C) relationship, which ultimately leads to satisfied and loyal customers (Zott, Amit \& Donlevy, 2000). Given the harsh competition among the e-service providers, the quality of service is equally critical as any real world service firm since it helps them to capture and retain customers (Gounaris \& Dimitriadis, 2003).

Anderson and Srinivasan (2003) have investigated the impact of customer satisfaction on consumer loyalty in the context of e-commerce, and they defined consumer loyalty as the favorable attitude of the customers toward an e-business resulting in repeated buying behavior.

In traditional service industry, the behavioral consequences of loyalty have been documented to be extremely beneficial for the company (Zeithmal, Berry \& Parasuraman, 1996). Srinivasan, Anderson, \& Ponnavolu (2002, p. 42) mentioned that it is also similarly beneficial in the context of e-commerce services. Loyal customers create bonds with the company and behave differently from non-loyal customers. Thus, consumer loyalty impacts behavioral outcomes and, ultimately, it influences the profitability of a company in a positive way. Loyal consumers are even willing to pay more to continue business with their preferred retailers rather than incurring additional cost for alternative search (Reichheld \& Schefter, 2000). Wang (2010) found out positive implication of loyalty on company revenue and profitability. Mattila (2001), noted that loyal consumer provide positive word-of-mouth which helps the company to get more consumers. Thus, the importance of consumer loyalty for e-commerce is as great as traditional commerce, if not greater.

After two decades of its introduction, e-commerce now amounts to a significant portion of all the commercial activities. The increasing importance of e-retailers in e-commerce and the relationship between e-service quality and consumer loyalty has provide us with a scenario 
which encourages us to go deeper into this issue and delivers a good point of departure for our research

\section{Electronic service quality}

Zeithaml defined e-service quality as the extent to which a web site facilitates efficient and effective shopping, purchasing, and delivery of product and services. We found that the definition of Zeithaml et al. for e-service quality to be more acceptable.

The web platform is fundamentally different from real life traditional commerce. In real life, the consumers do not process all the elements of the service, while in online environment each sub-process has a greater probability to be noticed by the consumers. Consumers can spend as much time as they want in the e-retailing stores (Lee and Lin, 2005, p. 163). In addition to that, the purchase process is not administered by any sales representative. That's why the consumers have to go through the whole process themselves. Hence customers are likely to perceive the e-service as a whole process and outcome (van Riel et al. 2001).

The web environment is fundamentally different from the real life situations. Thus while evaluating the e-service quality; the consumers are more likely to evaluate each sub-process in details as the virtual environment gives them the freedom to spend as much time as they want. Moreover, absence of any service representative makes them to go through the whole process themselves. Thus, customers are likely to perceive the e-service as a whole process and outcome (van Riel et al. 2001). In a research conducted by Meuter et al. (2000), it is found that consumers are more likely to be affected by negative incidents rather than be satisfied with positive performances in context of e-service. It is very easy to compare products of different eretailers on the internet. Thus the quality of e-service is of immense important for the service providers. For online consumers, e-service quality is the prime factor to distinguish between any two service providers (Santos, 2003)

Price is an important factor of service quality evaluation. Retailers can ensure long-term earnings by following a consistent pricing policy. Rabinovich and Bailey (2004, p. 655) suggested that service quality is proportional to price as long as the transaction contracts are short-term in nature, a likelihood of future contact between the e-service provider and buyer exists, and the consumers have the option to select among providers. In this setting of e-commerce consumers have the option to compa re between service providers easily (Santos, 2003, p. 235). Moreover since consumer electronic product market is a very competitive market, the difference in price level of different providers is very marginal. These factors alleviate the moderating effect of price on the e-service quality evaluation.

Consumer loyalty in an online environment is necessarily generated from a higher evaluation of service quality provided by the e-retailers (Reichheld and Schefter, 2000). Therefore, service is of highest emphasis for e-commerce service providers. A well-designed website is not only effective to attract the attention of online consumers; it can also create awareness in the offline community. With the functionalities of recent technologies, e-service quality can influence the consumers to get involved with the product development process through customization and feedback and thus can build up stronger relationship with the consumers. A customer's engagement and assessment of the e-service quality determine the actions of the customer (Gounaris, Dimitriadis and Stathakopoulos, 2010, p. 143). 


\section{Dimensions of Electronic Service Quality}

E-service quality has been defined as the extent to which a Web site facilitates efficient and effective shopping, purchasing, and delivery (Zeithaml et al. 2000, p. 11). However, now the academics argue that this definition is too narrow and e-service quality should cover the complete spectrum of service offering, rather than focusing exclusively on transaction-specific elements. Thus, e-service quality now can be defined as the consumer"s evaluation of process and outcome quality of the interaction with service provider"s electronic channels (Gummerus et al., 2004)

There were several other dimensions in other articles and research works. But due to low frequency we screened those out primarily. However, after going through 20 articles on eservice quality which dealt with the dimensions, we have selected four dimensions which appeared most frequently and widely mentioned by different authors. These four dimensions are: Security, Responsiveness, and Reliability and Ease of use .

Consumer loyalty is the key concept of this study. There are a number of definitions of loyalty forwarded by different authors. However, these definitions are mostly complementary, not contradictory. Oliver (1999) defined "consumer loyalty as a commitment to re-buy or repatronize a preferred product/ service again and again in the future". Neal (1999) thinks consumer loyalty is a behavior and defines consumer loyalty as 'the proportion of times a purchaser chooses the same product or service in a specific category compared to the total number of purchases made by the purchaser in that category, under the condition that other acceptable products or services are conveniently available in that category (Neal, 1999, p. 21). Anderson and Srinivasan (2003, p. 125) investigate the impact of consumer loyalty in the context of e-commerce, and consumer loyalty is defined as the customers favorable attitude toward an e-business resulting in repeat buying behavior. The favorable attitude does not necessarily mean satisfaction; it can be other attitudinal outcome as well such as intention to share with others, pleasure, trust and so on.

We decided to adopt the definition of loyalty constructed by Chang, Wang and Yang (2009) which encompassed all the definitions which viewed consumer loyalty as a commitment of repeatedly buying a preferred product/service and positive WOM consistently after making the first purchase.

Thus, consumer loyalty can be identified with three characteristics exhibited by a consumer:

a. Repeat purchase behavior

b. Positive attitude towards the service provider; and

c. Positive Word of mouth

A loyal consumer group of a company can make a huge difference as they not only try to engage other people with the company; they are also less likely to be motivated by the competitor campaign and negative expert opinion (Narayandas, 1998). Interruption of web service is something that even the largest online companies cannot totally avoid. In this context, loyal customers are particularly beneficial for the company as they tend to show a greater level of tolerance for waiting when the service is interrupted (Narayandas, 1998).

The electronic retailer provides e-service quality through the website. According to the Chen and Dubinsky (2003, p. 325), consumer loyalty depend on the e-commerce after having experience of e-service quality through the website of e-retail offering. After receiving the 
perceive value from the e-service quality through e-retail offering leads to customer loyalty. According to the Chang and Wang (2010, p. 341), e-service quality in the e-retail offering creates value for the customer where customer receive perceived value from their expectation which impacts their attitude toward the service provider positively which in turns leads to positive WOM, repeat purchase and ultimately consumer loyalty. Hence, e-service quality enhances consumer loyalty (Carlson and O'Cass, 2010). Thus, an impact of e-service quality on consumer loyalty is evident from the empirical scholarly works. However, these studies examined the relationship on a broad e-commerce context. In our case, we do not know whether the dimensions of e-service quality impact consumer loyalty in a similar fashion or not. But we can assume that the impact is likely to be positive.

Thus we forward our first hypothesis as:

H1. E-service quality positively influences consumer loyalty for e-retailers providing consumer electronic goods

\section{SECURITY}

One of the most critical customer concerns is the issue of security, i.e. the extent to which customers believe the site is safe to use and that personal information is protected (Zeitha ml et al. 2000).

Security is a great concern for a number of consumers as online fraudulent activities are in abundance. E-service providers need to assure the consumer that the transactions are completely secured. Consumers are often concerned about the information storage policy of the retailers. E-retailers often use cookies (a text file that can track the users activities on the website) to make customized recommendation for the consumers. E-retailers need to be very clear that none of their activities are threatening the security of the consumer (Yang and Jun, 2002).

Non-transactional privacy requires for instance Web cookies or unsolicited e-mail which may affect consumer"s use of Web sites (Korgaonkar \& Wolin, 1999). Although security sometimes equated with trust (Reichheld \& Schefter, 2000), it can also be assumed to be a distinct dimension. Since most of the e-commerce site guarantees complete anonymity, security is based on the consumer"s perceptions of the security policies and their beliefs that they can safely use the site without being tracked down. Security is directly related to loyalty since it signals the service provider"s integrity. Thus we proceed to propose our second hypothesis as:

H2: Security positively influences consumer loyalty

\section{RESPONSIVENESS}

Responsiveness requires the service provider"s able to respond sharply to requests and suggestions, and to give assistance for customers in case of problems (Zeithaml et al. 2000). Customers have recognized a fast response as a tool of high-quality service (Voss, 2003), but in practice many companies fail on this dimension (Kaynama \& Black, 2000). Here, responsiveness is defined as the magnitude to which customer feedback is taken into attention, and the promptness of reply. 
Consumers expect that the e-retailers must respond to their inquiries promptly. Though Yang and Jun $(2002$, p. 35$)$ has observed that in comparison to physical service providers, e-retailers often lack real-time interaction with the customers.

Two important aspects regarding responsiveness are the speed of information retrieval and the load time of website. Consumers want to find accurate information quickly. If the loading time of the website is delayed, the consumer might look for another provider (Yang \& Jun, 2002, p. 35).

Since responsiveness reflects customer"s perceptions of the service provider"s ability and willingness to respond to customer needs, it is also expected to impact loyalty.

As a consequence, we expect:

H3. Responsiveness positively influences consumer loyalty

\section{RELIABILITY}

Reliability means the correctness of order fulfillment, prompt delivery, and billing accuracy (Yang, 2001). Reliability is a widely used dimension of service quality and its prolific use made it an essential component of the quality. Reliability is a dominant dimension of traditional service quality. In case of e-service quality, it has no less importance. Wolfinbarger and Gilly (2002) found out that customer loyalty and/or intentions to repurchase can be predicted from reliability ratings. Zeithaml, Parasuraman and Malhotra (2002, p. 364) suggested that reliability is formed from on-time and accurate delivery, accurate product representation, and other fulfillment issues. It may also reflect technical reliability such as the proper functioning of the website (Zeithaml et al., 2002, p. 364).

Thus as we proceed to propose our fourth hypothesis as:

H4. Reliability positively influences consumer loyalty

\section{EASE OF USE}

Ease of use is defined as how easy the Web site is for customers to operate external search in cyberspace and internal navigation and search within the Web site (Gummerus et al., 2004). External search indicates to the point to which customers can easily find the Web site on the worl dwide Web.

An easily memorable name is important for online consumers. E-retailers must avoid complex names. To convert the people who searched for information into consumers the quality of information regarding the products and the convenience of using the information is crucially important. The structure of the e-store needs to be easy to understand and navigate (Yang \& Jun, 2002).

The use of set-up web links with major internet search engines and comprehensive URL addresses are systems that help to achieve this objective. There was a very high demand for a Web site which is easy to find, navigate and use within. Users favored "quick-finders" and "user guidelines" (Santos, 2003). The level of the ease of use is expected to affect loyalty directly, since it provides physical evidence of the service provider"s competence as well as facilitating effortless use of the service (Gummerus et al., 2004). 
It possessions aspect for example overall Web site design (Kaynama \& Black, 2000), including layout (Srinivasan et al., 2002), ease of navigation (Kaynama \& Black, 2000; Zeithaml et al. 2000) ease of use (Dabholkar, 1996; Srinivasan et al. 2002) and site aesthetics (Zeithaml et al. 2000). Roy et al., (2001) suggest that ease of interface design, navigation, and user guidance affect consumer establishment of loyalty. Thus we propose the fifth hypothesis in relation with ease of use:

H5. Ease of use positively influences consumer loyalty

All the item-total correlation is greater than 0.5 that indicate a positive conclusion about validity of our composite variables. And the value of Cronbach" $s$ alpha is greater than 0.5 for all five composite variables. With short scales (e.g. scales with fewer than ten items) it is common to find quite low Cronbach values (Pallant, 2010). So, we can make a positive conclusion about validity and reliability about the variable choice of our study.

To analyze the demographic factors of our respondents we get $54.5 \%$ are male and $45.5 \%$ are female. Among all the respondents $47.5 \%$ are bachelor level and $52.5 \%$ are masters level student. Another point is that most (49.5\%) of our respondents are young, who fall within the age group of $18-22$

\section{Relationship between E-Service Quality and Consumer Loyalty}

To measure the strength of the relationships between the e-service quality and consumer loyalty, we have used Pearson"s R in SPSS. Pearson"s R can range from - 1 to +1 (Pallant, 2010). A Positive Correlation indicates that one variable increases so does the other variable increase. A negative correlation indicates that one increases, the other decreases (Pallant, 2010).

\section{Methodology}

This research is descriptive research and population consisted of internet users in Isfahan city that have been purchase form internet at least one time. The study is used random sampling. The participants showed their agreement with a set of statements, using a 7-point Likert-type scale.The questionnaire were distributed among people who purchase from internet . Out of 260 questionnaires, 250 were return with completed answers and were used in statistical analyses .In order test proposed hypotheses, we collected data and analyzed it with using structural equation model (SEM). SEM is a general technique in some fields including marketing , social sciences and psychology .SEM is a second-generation multiva riate that use confirmatory factor analysis with multiple regressions and estimate some of interrelated dependence relationships simultaneously ..Hence, the structural equation model. This study use Amos software to analyze data. We used measurement model to test validity and reliability of questions and variables in the proposed model. Table 1 are showed Results of path analysis. We considered several model fit measures to assess the model's overall goodness-of-fit: at first the ratio of $X 2$ to degrees-of freedom (d.f.), , the adjusted goodness-of-fit index (AGFI), the root mean square residual (RMR), the norm fit index (NFI), the comparative fit index (CFI), , the root mean square error of approximation (RMSEA) and the goodness-of-fit index (GFI). Figure 2 shows the results with a non-significant path and standardized path coefficients between the research constructs. Consumer loyalty was significantly influenced by service quality .Thus Hypotheses 1 was supported. 


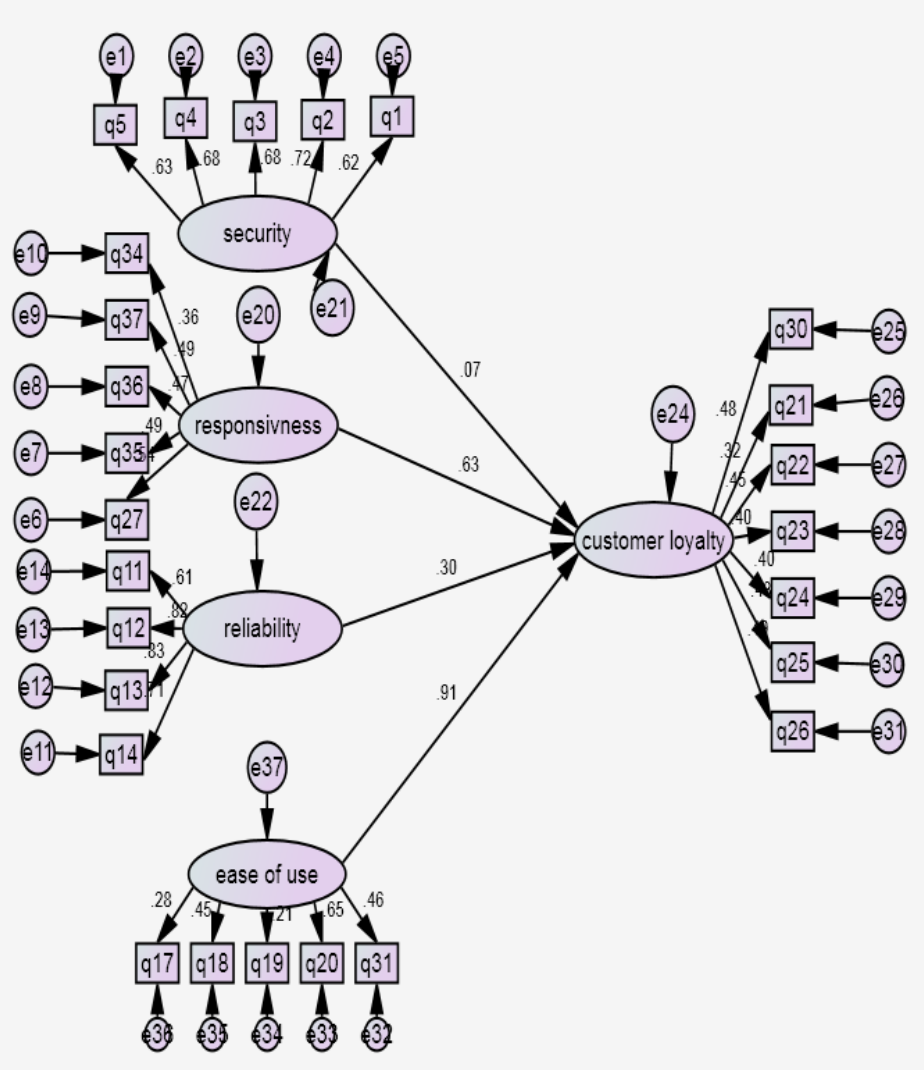

Customer loyalty was not affected by security but responsiveness, reliability and ease of use were affected loyalty thus hypotheses 3 to 5 were supported.

\begin{tabular}{|l|l|l|l|l|l|l|l|l|}
\hline Index & CMIN/DF & P & RMR & GFI & AGFI & TLI & CFI & RMSEA \\
\hline Value & 4.02 & 0.021 & 0.038 & 0.95 & 0.88 & 0.937 & 0.999 & 0.04 \\
\hline
\end{tabular}




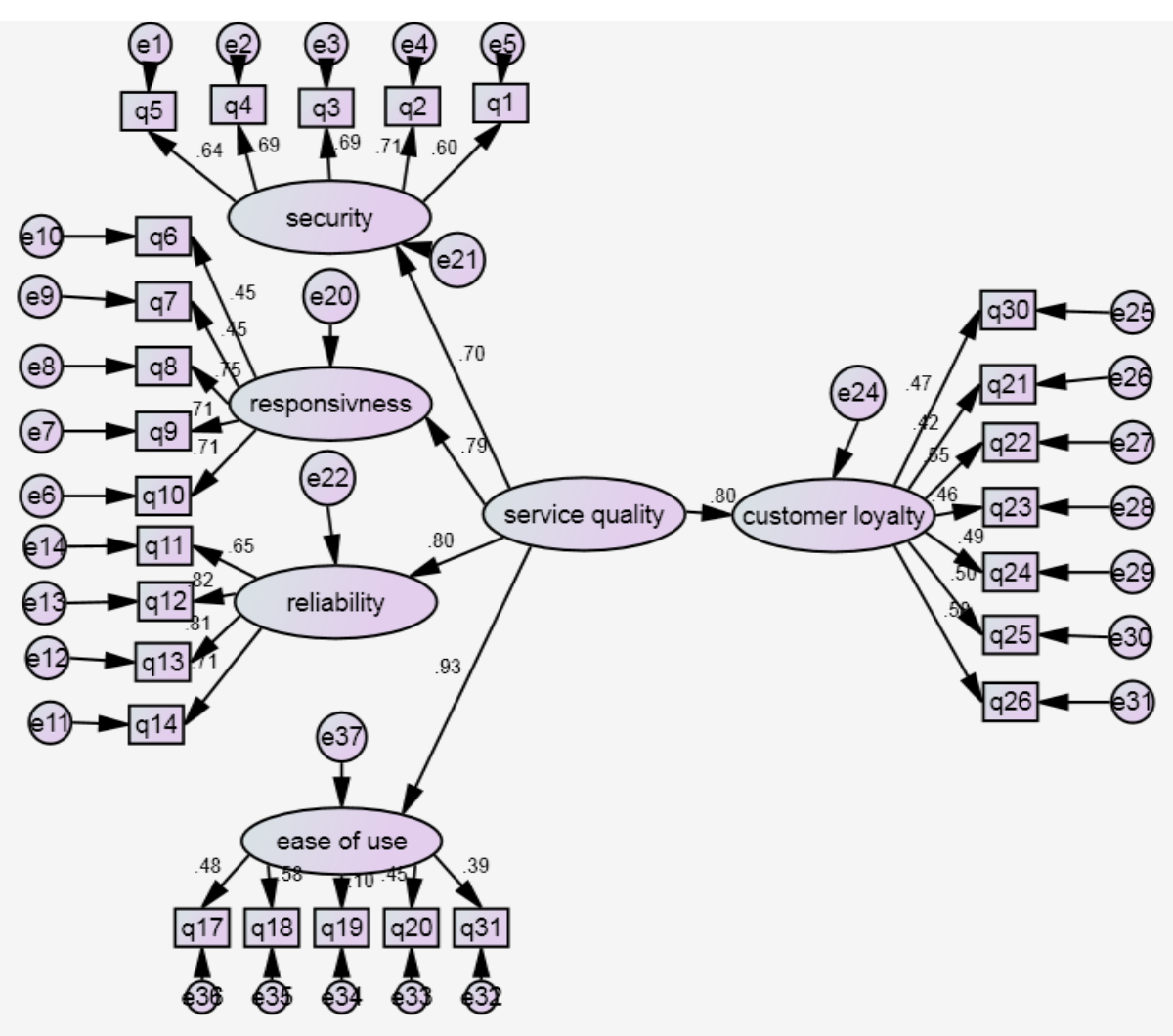

Table 4. The result of hypotheses testing (regression weights)

\begin{tabular}{|lrl|lll|}
\hline Hypotheses & & Description & Estimate & C.R. & P \\
\hline Customer loyalty & $<---$ & service quality & 0.80 & 6.194 & $* * *$ \\
Customer loyalty & $<---$ & security & 0.07 & 1.07 & 0.21 \\
Customer loyalty & $<---$ & responsiveness & 0.63 & 5.578 & $* * *$ \\
Customer loyalty & $<---$ & Reliability & 0.30 & 4.762 & $* * *$ \\
Customer loyalty & $<---$ & Ease of use & 0.91 & 8.865 & $* * *$ \\
\hline
\end{tabular}




\section{Conclusion}

The objective of this study was to examine the relationship between e-service quality and consumer loyalty. On the basis of empirical literature, we sorted out four defining dimensions of e-service quality that has a relationship between consumer loyalties. Statistical significance of the impact of each chosen variable on consumer loyalty has supported our selection. After conducting the survey on the consumers.

In the theoretical discussion, we have defined Security as the extent to which customers believe the site is safe to use and that personal information is protected. From the interpretation of our analysis, it can be suggested that Security is mostly perception-driven. The sense of feeling secured in the transaction with a particular e-retailer largely depends on how the customer perceives the store. Our respondents have given the highest important on the well organization of a website among the mentioned factors in the questionnaire and the second highest value was given to the factor of feeling safe in making transaction. Thus, these two observations can be related in a way that Ease of use or the presentation of the e-retailer store has immense importance on the perception of security. A strong correlation between Ease of use and consumer loyalty has also been observed. The second dimension that we chose was responsiveness, which is defined as the extent to which consumer get feedback. We discussed in the theoretical part that as responsiveness reflects consumers' perception of the service provider's ability and willingness to response to consumers' demand. Our respondents have reflected that by showing a significant relationship between responsiveness and loyalty. Among the three main factors, respondents have given the highest value to the quality of promptly getting back to consumers. Kaynama and Black (2000) observed that many companies fail to promptly respond to consumers. Considering the high importance of promptly getting back to consumers, companies have the scope to create competitive advantage here by ensuring proper responsiveness. We also inferred from our analysis that the degree of Responsiveness is more likely to be perceived by the consumer rather than be experienced. So the manager needs to make sure that the website has all the options of a responsive interface i.e. live chat, email support, feedback form, apps and widgets to share and a helpful FAQ section. Thus studying and analysing of our four selected variables of e-service quality, we have found that the selected variables of e-service quality is most important factor for retailer for consumer loyalty. However, we have found our research question that there has a relationship between e-service quality and consumer loyalty towards electronic store retail market.

\section{References}

Anderson, R.E., \& Srinivasan, S.S. (2003). E-satisfaction and e-loyalty: a contingency fra mework. Psychology and Marketing journal, 20 (2), 123-138.

Carlson, J \& O"Cass, A. (2010). Exploring the relationships between e-service quality, satisfaction, attitudes, and behaviors in content-driven e-service web sites. Journal of Services Marketing, 24 (2), 112-127.

Dabholkar, P.A. (1996). The convergence of customer satisfaction and service quality evaluations with increasing customer patronage. Journal of Consumer Satisfaction, Dissatisfaction and Complaining Behavior, 8, 32-43.

Gounaris. P., \& Dimitriadis. (2003). Assessing service quality on the web: evidence from business to consumer portals. Journal of service marketing, 17 (5), 529-548. 
Gummerus, J., Liljander, V., Pura, M., \& Riel, A. (2004). Customer loyalty to content-based web sites: the case of an online health-care service. Journal of service marketing, 18 (3), 175-186.

Kaynama, S.A., \& Black, C.I. (2000). A proposal to assess the service quality of online travel agencies: an exploratory study, Journal of Professional Services Marketing, 21 (1), 63-88.

Kaynama, S.A., \& Black, C.I. (2000). A proposal to assess the service quality of online travel agencies: an exploratory study, Journal of Professional Services Marketing, 21 (1), 63-88.

Korgaonkar, P.K., \& Wolin, L.D. (1999). A multivariate analysis of Web usage, Journal of Advertising Research, 39 (2), 53-68

Lexhagen, M. (2009). E-marketing and customer perceived value in travel and tourism: European Tourism Research Institute (ETOUR).

Mattila.A.S, (2001). The impact of relationship type on customer loyalty in a context of service failure. Journal of service research, 4 (2), 91-101.

Meuter, M.L., Ostrom, A.L., Rountree, R.I., \& Bitner, M.J. (2000). Self-service technologies: understanding customer satisfaction with technology-based service encounters. Journal of Marketing, 64 (3), 50-64

Narayandas, D. (1998). Measuring and managing the benefits of customer retention: an empirical investigation. Journal of Service Research, 1 (2), 108-28

Neal, W.D. (1999). Satisfaction is nice, but value drives loyalty. Marketing Research, 11 (1), 2123.

Pallant, J. (2010). SPSS survival manual, a step by step guide to data analysis using SPSS. 4th edition. Allen and Unwin. Mcgraw-Hill.

Ponirin, P, Scott, D.R., Von Der, H. (2010). Does e-store service quality affect customer loyalty? Social Science Research Network, viewed 19th January.

Reichheld, F., \& Schefter, P. (2000). E-loyalty: Your secret weapon on the web. Harvard Business Review, 78 (4), 105-114.

Reichheld, F., \& Schefter, P. (2000). E-loyalty: Your secret weapon on the web. Harvard Business Review, 78 (4), 105-114

Ribbink, D., Van Riel, A.C.R., Liljander, V. \& Streukens, S. (2004). Comfort your online customer: quality, trust, and loyalty on the internet. Managing Service Quality, 14 (6), 446-456.

Robinovich. E., Bailey, J.P. (2004). Physical distribution service quality in internet retailing: service pricing, transaction attributes and firm attributes. Journal of operations management, 21, 651-672.

Santos, J. (2003). E-service quality: a model of virtual service quality dimensions. Managing service quality, 30 (3), 233-246.

Srinivasan, S.S., Anderson, R., \& Ponnavolu, K. (2002). Customer loyalty in e-commerce: an exploration of its antecedents and consequences. Journal of Retailing, 78 (1), 41-50.

Singh, T., Gordon, G., \& Purchase, S. (2007). B2B e-marketing strategies of multinational corporations: Empirical evidence from the United States and Australia. Mid-American Journal of Business, 22 (1), 31.

Van Riel. A.C.R, Liljander, V., \& Jurriens. P. (2001). Exploring consumer evaluations of e-services: A portal site. International journal of service industry management, 12 (4), 359-377.

Wang, C. (2010). Service quality, perceived value, corporate image, and customer loyalty in the context of varying levels of switching costs. Psychology and marketing journal, 27 (3), 252-262. 
Wolfinbarger, M., \& Gilly, M.C. (2003). eTailQ: Dimentionalizing, measuring and predicting etail quality. Journal of retailing, 79 (3), 183-198.

Wu. K.W., (2011). Customer loyalty explained by electronic recovery service quality: Implications of the customer relationship re-establishment for consumer electronics e-retailers. Contemporary management research, 7 (1), 21-44.

Yang, Z., Jun, M., \& Peterson, R.T. (2004). Measuring customer perceived online service quality: Scale development and managerial implications. International Journal of Operations and Production Management, 24 (11), 1149 - 1174.

Zeithaml, V. A., Berry, L. L., \& Parasuraman, A. (1985). A conceptual model of service quality and its implications for future research. Journal of marketing, 43, 41-50.

Zott, C., Amit, R., \& Donlevy, J. (2000). Strategies for value creation in E-commerce: Best practice in Europe. European management journal, 18 (5), 463-475. 